\title{
„ZAPOWIADA SIĘ NADZWYCZAJNY AKTOR”. KAROL WOJTYŁA W PODZIEMNYM TEATRZE RAPSODYCZNYM
}

Po jednym ze spektakli Króla-Ducha, przygotowanym przez konspiracyjny zespół Teatru Rapsodycznego, nieskory do wyrażania pochlebnych opinii Tadeusz Kwiatkowski o występie swojego kolegi z uniwersyteckiej polonistyki, Karolu Wojtyle, zawyrokowat:

- To będzie kiedyś wielki aktor.

- Zapowiada się nadzwyczajny aktor - stwierdził Juliusz Osterwa, często goszczący na przedstawieniach.

- Tak, zdolny, bardzo zdolny - rzekł Władysław Woźnik, sam świetny wykonawca Promethidiona i Beniowskiego.

Te zdania umocniły mnie w przekonaniu, że jedyną drogą dla Karola będzie po wojnie teatr, teatr ogromny, o jakim marzył Stanisław Wyspiański. (Młodzieńcze lata 78)

Obok znakomitych umiejętności i warunków scenicznych, umiejętności intelektualnego zmagania się z tekstem, charyzmatu przełamywania dystansu pomiędzy aktorem i widzem, posiadał Wojtyła znaną już nie tyle widowni, ile osobom z jego koleżeńskiego kręgu łatwość w opanowaniu tekstu scenicznego, nie tylko zresztą w zakresie swoich ról, ale i ról swoich scenicznych partnerów. Tadeusz Kwiatkowski wspominat:

Byłem tylko pośrednim towarzyszem grupy Kotlarczyka, która pracowała bez przerwy, a ponieważ próby bardzo często odbywały się w suterenowym mieszkaniu Karola blisko mnie, widywaliśmy się parę razy w tygodniu. Karol zawsze pierwszy umiał tekst na pamięć, ba, potrafił w każdej chwili zastąpić kogoś z zespołu, gdy jakieś zajęcia nie pozwoliły mu przyjść w danym dniu. Po-

Dr STANISŁAW DzIEDZIC - historyk literatury, publicysta, animator kultury, nauczyciel akademicki UJ; e-mail: Stanislaw.dziedzic@biblioteka.krakow.pl 
dziwialiśmy tą jego zdolność szybkiego przyswajania sobie trudnych przecież utworów. A było co do wkuwania, bo przedstawienia trwały nieraz ponad godzinę. Nie wiem, jak to robił... Ta umiejętność zapamiętywania przyczyniła się też zapewne do wysokich not, jakie otrzymywał stale przy wszelkiego rodzaju egzaminach w szkole średniej i na uniwersytecie. (Młodzieńcze lata 79)

Zanim Karol Wojtyła zaświadczył w sensie publicznym o swojej fenomenalnej pamięci, nie tylko w odniesieniu do warunków scenicznych, jeszcze w wadowickim zespole doszło do zdarzenia, które mogło się skończyć dla młodych adeptów sztuki teatralnej prawdziwą katastrofą. Dnia 14 lutego 1937 roku miała się tam odbyć premiera Balladyny, w reżyserii Mieczysława Kotlarczyka, bo oto „tuż przed premierą" dyrektor Gimnazjum Męskiego Jan Królikiewicz wobec jednego z uczniów - aktorów zastosował surową karę, która w istocie była karą dla całego zespołu. Gdy oto jeden z uczniów - aktorów, Bolesław Pomezański, zagroził nauczycielowi, że w przypadku otrzymanej oceny niedostatecznej zastrzeli go (w istocie przyniósł do szkoły straszaka), dyrektor nie dopuścił go do występu w roli Kostryna.

Ziemia nam się usuwa spod nóg - wspomina Halina Królikiewiczówna, córka dyrektora szkoły A Lolek Wojtyła spokojnie mówi: „Nie martwcie się mój Kirkor to mała rola, umiera na wojnie, więc się przecharakteryzuję i zagram również Kostryna”. Obdarzony wspaniałą pamięcią, nie zmienia nawet wersu w trudnym jedenastozgłoskowcu Słowackiego. (Kwiatkowska, Porachunki z pamięcia 18)

Karol Wojtyła już w okresie gimnazjalnym wyróżniał się wśród swoich rówieśników, występujących zarówno w spektaklach szkolnych Kółka Teatralnego, jak i prowadzonego przez Mieczysława Kotlarczyka Amatorskiego Teatru Powszechnego, oraz na scenie wadowickiego Domu Katolickiego swoim przygotowaniem aktorskim, ale także umiejętnościami reżyserskimi. W późnych klasach gimnazjalnych powierzano mu role wiodące, dla każdej z tych scen współreżyserował spektakle - Nie-Boska komedię, Apokalipsę, a na scenie szkolnej wraz ze swoim polonistą, Kazimierzem Forysiem, przygotował śmiałą, znakomicie scenicznie przemyślaną adaptację Zygmunta Augusta wg dramatu Stanisława Wyspiańskiego. Na kilka lat przed powstaniem Teatru Rapsodycznego, właśnie on jako pierwszy, a nie jego mistrz, Mieczysław Kotlarczyk, przygotował i z niemałą konsekwencją inscenizacyjną, wyreżyserował Zygmunta Augusta w duchu wspólnych z Kotlarczykiem przemyśleń artystycznych.

Wybór studiów uniwersyteckich wszechstronnie utalentowanego gimnazjalisty, o dostrzegalnych humanistycznych preferencjach, obdarzonego wyrazistymi predyspozycjami artystycznymi nie był w Wadowicach ani w jego środowisku rówieśniczym większym zaskoczeniem. Studia polonistyczne, wobec braku w Krakowie szkoły teatralnej o charakterze profesjonalnym i akademickim, były - jako ukierunkowane na zgłębienie fenomenu scenicznego słowa najbliższe jego artystycznym 
zainteresowaniom. Wykraczały one poza sferę teatru, aktorstwa i reżyserii, bo już w okresie gimnazjalnym Karol Wojtyła podejmował próby literackie, jako poeta, a we wczesnym okresie akademickim napisał cztery dramaty, z których trzy pierwsze: Dawid, Hiob i Jeremiasz będą się wręcz nazywać dramatami polonistycznymi. Ale o ile o sukcesach i pasjach scenicznych Wojtyły wiedziano tam powszechnie, o poczynaniach literackich mogła wiedzieć co najwyżej garstka osób z jego najbliższego otoczenia. Argumentację tamtych wyborów ujął po latach on sam w autobiograficznej książce Dar i Tajemnica, która powstała w 50. rocznicę jego święceń kapłańskich:

Jeśli młody człowiek o tak wyraźnych skłonnościach religijnych nie szedł do seminarium, to mogło rodzić domysły, że wchodzi w grę sprawa jakichś miłości czy zamiłowań [...]. W tamtym okresie decydujące wydawało się nade wszystko zamiłowanie do literatury, a w szczególności do literatury dramatycznej i do teatru. Zamiłowaniu do teatru dał początek starszy ode mnie polonista Mieczysław Kotlarczyk. Był on prawdziwym pionierem - amatorskiego teatru o wielkich ambicjach repertuarowych. (Dar i Tajemnica 8)

Karol Wojtyła w sztuce recytacji był już w czasach wadowickich odrębny, nie bez wpływów Mieczysława Kotlarczyka, rychło zdołał wykształcić własną ,szkołę”, opartą na intelektualnym mierzeniu się z ideą słowa, rezygnacji z powszechnych wówczas stylizacji czy egzaltacji. Ten styl prezentowania tekstu scenicznego stawał się coraz bardziej wyrazisty po 1936 roku, kiedy Wojtyła poznał Mieczysława Kotlarczyka, a początkowe ich relacje typu nauczyciel - uczeń z czasem stały się artystycznie partnerskie.

Umiejętności interpretacyjne i sposób recytacji swoich wierszy przedstawił przed krakowską publicznością już jako student polonistyki uniwersyteckiej, podczas wieczoru autorskiego Droga topolowy most, w Sali Błękitnej Domu Katolickiego (ob. gmach Filharmonii Krakowskiej), 15 października 1938 roku. Wiersze grupy koleżeńskiej: Jerzego Bobera, Jerzego Kałamackiego, Tadeusza Kwiatkowskiego i Karola Wojtyły, określanych w zajawkach prasowych jako najmłodsza grupa poetycka Krakowa, recytowali koleżanki i koledzy ze środowiska uniwersyteckiego, a tylko Karol Wojtyła osobiście deklamował swoje utwory poetyckie. Wśród młodych poetów wyróżniał się zarówno prezentowanymi utworami, tradycyjnymi w sferze formy gatunkowej, jak i sposobem ich recytacji. Niewielu uczestników z wypełnionej po brzegi sali zapamiętało te wiersze, poza nieścisłymi stwierdzeniami, że dotyczyły tematyki postczartakowskiej, beskidzkiej, w pamięci wielu osób pozostał zgodnie wypowiadany zachwyt związany ze sposobem ich wygłoszenia. Danuta Michałowska, licząca natenczas zaledwie piętnaście lat, ale już z niemałymi sukcesami występująca jako recytatorka w krakowskich konkursach i akademikach, z czasem czołowa artystka sztuki recytatorskiej i twórczyni teatru jednego aktora, zobaczyła i usłyszała tego wieczoru Karola Wojtyłę po raz pierwszy i mimo upływu wielu 
lat - wspomina tamten wieczór jako wielkie wydarzenie, w kontekście spotkania z niezwykłym aktorem.

Była to - wyznaje - recytacja wyrazista i prosta zarazem, nacechowana nieskazitelnie precyzyjną dykcją i zupełnie swoistą melodią frazy wiersza. Wreszcie głos: o szczególnie pięknej barwie, ciepły, miękki, niezbyt niski, wyrażający jakąś niepowtarzalną, jego własną i jemu tylko właściwą intymność; zarazem nośny i dźwięczny, doskonale słyszalny, już wtedy przeznaczony do rozbrzmiewania na wszelkich placach [...] Czy muszę udowadniać, że zrobił na mnie szczególne wrażenie, iż rozpoznawałam go natychmiast, kiedy w kilka miesięcy później powtórnie usłyszałam Karola Wojtyłę [...] w poetyckim spektaklu pióra Mariana Niżyńskiego Kawaler księżycowy, osnutym na temacie pana Twardowskiego. (,Spotkanie z aktorem Teatru Rapsodycznego” 226)

Wspomniany przez Danutę Michałowską Kawaler księżycowy, którego premiera odbyła się 7 czerwca na dziedzińcu uniwersyteckim Kolegium Nowodworskiego, był spektaklem warsztatowym słuchaczy roku Studia Dramatycznego 39. Karol Wojtyła, podobnie jak kilkoro jego koleżanek i kolegów z uniwersyteckiej polonistyki, uczestniczył w zajęciach tej szkoły, prowadzonej przez Tadeusza Kudlińskiego i Wiesława Goreckiego. Niestety, jej działalność rychło została przerwana wybuchem wojny światowej. „Rozbitkowie” ze Studia 39, zanim w zmienionym już składzie dali początek Teatrowi Rapsodycznemu, w konspiracyjnych z konieczności warunkach, kontynuowali pod opieką Tadeusza Kudlińskiego działalność w zakresie zarówno pogłębionej wiedzy teoretycznej, jak i kształcenia warsztatu scenicznego. Do prac tych na wiosnę 1940 roku pozyskano pracującą w Spółdzielni „Społem” Danutę Michałowską. Współpracę z ,grupą Kudlińskiego” wiosną 1940 roku podjął Juliusz Osterwa. Młodzi adepci postanowili w warunkach domowych wystawić dramat Uciekła mi przepióreczka, napisany przez Stefana Żeromskiego, właśnie dla Osterwy. Ostatecznie inscenizację ograniczono do drugiego aktu. Karol Wojtyła, który reżyserował Przepióreczkę, rolę Smugoniowej powierzył Danucie Michałowskiej, Przełęckiego - Juliuszowi Kydryńskiemu, sam zaś przejął rolę Smugonia. Po premierze, która odbyła się w mieszkaniu Kydryńskich przy ul. Felicjanek 10, zachwycony występami Michałowskiej i Wojtyły, Juliusz Osterwa zapowiedział, że z ich osobami wiązał będzie odtąd nadzieje sceniczne w Teatrze im. Juliusza Słowackiego. Warto dodać, że na czas powojenny konspiracyjna Rada Miasta Krakowa przyznawała Osterwie funkcję dyrektora tej właśnie sceny. W przypadku Karola Wojtyły na przeszkodzie w tym względzie stanęły względy wyższej natury: podjęcie studiów teologicznych i zamiar wstąpienia do Karmelu.

Danuta Michałowska, utalentowana partnerka sceniczna Karola Wojtyły z Przepióreczki, o swoim niespełnieniu w tym względzie napisała:

Przepióreczka to ważny etap w moim życiu artystycznym, a Juliusz Osterwa, który zamierzał po wyzwoleniu otworzyć sezon w Teatrze im. Juliusza Słowackiego właśnie tym dramatem, chciał, abym to ja w nim grała w owym inauguracyjnym pierwszym powojennym sezonie polskim spek- 
taklu. Różne siły i błahe w gruncie rzeczy przyczyny złożyły się na to, że plan Osterwy się nie powiódł. On sam, dostrzegłszy mnie pewnego wieczoru za kulisami, kiedy właśnie zszedł ze sceny w kostiumie Przełęckiego, powiedział z jakimś szczególnym odcieniem żalu: „Moja przepióreczka - uciekła mi”. I zapytał, dlaczego się nie zgłosiłam...

Zawsze w moim życiu coś wychodziło nie tak, jak mogło, a zarazem zawsze właśnie tak, jak powinno. Moje miejsce było widoczne gdzie indziej, zawsze jakieś ,przypadki” sterowały moim losem wbrew prostej logice. (Pamięć nie zawsze święta 129)

Karol Wojtyła pozostając pod mocnym wpływem Osterwy, artysty o niekwestionowanym autorytecie artystycznym, rychło doszedł do przekonania, że bardziej przemawia do niego jednak Kotlarczykowska wizja teatru, która nie miała jeszcze sprecyzowanych stricte rapsodycznych założeń, ale liczne prerapsodyczne tezy były przez Kotlarczyka formułowane i wprowadzane do jego praktyki teatralnej. W liście do Kotlarczyka pisał:

Ty mi bardziej odpowiadasz. Na Osterwie bądź co bądź ciąży atawistycznie teatr [...] i niestety [...] Warszawa, my jesteśmy, że tak się wyrażę - prymitywniejsi. Chociaż ma czasem pomysły kapitalne [...] Aha, co najważniejsze - zdaje mi się, że Ty - mój Kochany Amatorze i Dyrektorze - zdaje mi się - podejrzewam - i wyżej mierzysz i dalej patrzysz, a o ile na razie jeszcze nie - to czuję, że dalej spojrzysz [...] Ale on fantastycznie mówi! Aktor to z niego musi być! (Kotlarczyk i Wojtyła 320)

W pamięci Karola Wojtyły pozostawały częste, wadowickie jeszcze spotkania w domu Kotlarczyków, w którym osierocony przez matkę młodzieniec przyjmowany był jako pełnoprawny członek rodziny, a wizytom tym towarzyszyły długie dyskusje o teatrze i literaturze. Spotkania te i dyskusje były kontynuowane w Krakowie, w mieszkaniu Zofii Kotlarczykowej, przy ulicy Długiej. Wojtyła - uczeń w tych relacjach ze starszym o 12 lat mistrzem i przyjacielem coraz częściej był rzeczywistym partnerem w ich strategicznych i teatralno-literackich dyskusjach. Kotlarczyk widząc jego solidną i dojrzałą wiedzę, liczył się bardzo z jego stanowiskiem w wielu kwestiach związanych z wyzwaniami, które stawiano przed polskim i europejskim teatrem. Drugi, ledwie rozpoczęty rok krakowskiej polonistyki był - o czym dowiadujemy się z listów Karola Wojtyły, kierowanych z ulicy Tynieckiej w Krakowie do Wadowic - czasem jego gruntownych indywidualnych już z konieczności studiów, także w zakresie sztuki teatralnej. Był to czas intensywnej pracy „rozbitków 39” i krzewienia wiary w odzyskanie wolności. Listy z wczesnego okresu okupacji, które pisał Wojtyła do Kotlarczyka, przenoszone były głównie przez Halinę Królikiewiczównę do Wadowic. Zachowały się one w zbiorach archiwalnych Mieczysława Kotlarczyka do naszych czasów. Niewiele wiemy o okupacyjnej korespondencji Mieczysława Kotlarczyka, o listach które pisał on do Karola Wojtyły. Najwięcej o ich zawartości możemy wnieść z samych listów Wojtyły do... Kotlarczyka. Na 
słowa Wojtyły z jego pierwszego listu: „Uniwersytet nieczynny. Teatr stoi” i na relację o marazmie pierwszych okupacyjnych tygodni - w drugim, Kotlarczyk nie szczędził mu słów nadziei w sferze budowania najszlachetniejszej sztuki, nieodległego teatralnego słowa, stosownie do wspólnych wizji i zamierzeń:

Wierzę - pisał w liście z 30 października 1939 roku - że ta straszliwa chwila, w jakiej wszyscy się znaleźliśmy nie zniszczyła wszystkiego. Miłość wielkiej sztuki trwa, zwycięży i zatriumfuje. Polska będzie Lolusiu, będzie prędzej niż nam się wydaje. A my będziemy awangardą Jej najszlachetniejszej sztuki, Jej teatru. Jej słowa. Będziemy. (Cyt. za: Malak)

Z czasem, gdy zespół pracujący pod opieką Tadeusza Kudlińskiego, artystycznie wspierany dorywczo przez Juliusza Osterwę, osiągnął już określoną sprawność warsztatową, wychodząc z coraz bardziej zróżnicowanym gatunkowo repertuarem poza stricte amatorskie prawidła, Kudliński uznał, że ze względu na swój wysoce ograniczony czas nie może zapewnić zespołowi tej opieki, na którą on zasługuje, nie chciał też nikogo narażać na niebezpieczeństwo z powodu jego zawodowego i politycznego zaangażowania. Kudliński, obok pracy zawodowej w banku i działalności literackiej, związany był z konspiracyjną katolicką organizacją „Unia”, funkcjonującą w porozumieniu z rządem polskim na emigracji. „Unia” wspierała finansowo artystów pozostających bez środków do życia, a także podziemne życie kulturalne i artystyczne. Sam Karol Wojtyła wstąpił do „Unii” zimą 1940 roku i został zaprzysiężony przez członka Komitetu Naczelnego „Unii” Stanisława Bukowskiego, przedwojennego działacza Akcji Katolickiej (on też dwa lata później zwolnił go ze ślubowania duchowego). „Unia” nie była organizacją o charakterze politycznym, zabiegającą o zdobycie władzy w Polsce w okresie powojennym, ale ruchem społecznym o chrześcijańskim światopoglądzie. Karol Wojtyła działał w zespole „Unia Kultury", którego prezesem był Artur Górski, a wiceprezesem - Tadeusz Kudliński. Bliskie mu były poglądy założyciela i przywódcy „Unii”, filozofa i poety Juliusza Brauna, o chrześcijańskich korzeniach europejskiej kultury i kryzysie duchowym współczesnego świata, dla którego szansą zachowania tożsamości i zażegnania upadku jest chrystianizm.

Listy Wojtyły do Kotlarczyka - stwierdza Jacek Popiel - potwierdzają, że krytyczna ocena współczesnej cywilizacji Zachodu, a przede wszystkim przedwojennej polskiej rzeczywistości, a także przekonanie o świecie coraz bardziej pogrążających się w anarchii i chaosie, o ginącej erze, stały się podstawą do snucia idei ściśle powiązanych z mesjanizmem, zapewne powiązanych z programem Brauna, ale u młodego Wojtyły konstruowanych głównie na podstawie dogłębnej lektury mistycyzmu pism Słowackiego [...] Wojtyła, tak jak duchowy przywódca unionizmu, był zafascynowany mistycznym Słowackim. Król-Duch, Genezis z Ducha stały się podstawowymi tekstami - przewodnikami duchowymi i zarazem programem działania w dziedzinie twórczości. Wojtyle bardzo bliski staje się również Norwid, który według Brauna „wzbił się” na wyższy stopień konkretności w swoim „misterium sztuki pracy”. (Popiel 272) 
Karol Wojtyła i jego wadowicka koleżanka, Halina Królikiewiczówna, wielokrotnie wspominali swoją współpracę z zespołem teatralnym Mieczysława Kotlarczyka i z nim samym, podkreślając jego doświadczenie w tym względzie, pasję działania i solidne wykształcenie uniwersyteckie, uwieńczone doktoratem. Kotlarczyk pochodził z rodziny o ogromnych zasługach w zakresie nieinstytucjonalnego ruchu teatralnego w Wadowicach. Marzyli o jego przyjeździe do Krakowa i o regularnych spotkaniach artystycznych pod jego kierunkiem i opieką. Osterwa słyszał o dokonaniach Kotlarczyka, czytał któryś z jego dramatów (Każdy) i popierał inicjatywę sprowadzenia do Krakowa Mieczysława Kotlarczyka. Tymczasem warunki wojenne skłaniały Kotlarczyka do opuszczenia Wadowic, w których za działalność patriotyczną aresztowany został jego starszy brat, Tadeusz, wywieziony do obozu w Mauthausen. Do położonego w Generalnym Gubernatorstwie Krakowa dostał się wraz z żoną m.in. dzięki pomocy konspiracyjnej „Unii” i otrzymał posadę konduktora w miejskim tramwaju. Kotlarczykowie, nie dysponując w Krakowie własnym mieszkaniem, ani środkami na jego wynajem, chętnie skorzystali z zaoferowanego im przez Karola Wojtyłę pokoju. Dzielili odtąd z nim skromne, dwupokojowe mieszkanie, położone w suterenie, przy ulicy Tynieckiej 10. Mieszkanie to, w domu Roberta Kaczorowskiego (brata matki Karola) było skromne, ale użyczone bezpłatnie. Mimo obowiązków zawodowych i uciążliwości wojennych, pochłaniających sporo czasu, znajdowali tam czas na dalsze dyskusje i snucie planów artystycznych.

Do zasadniczych wyznaczników, które uznawał za kluczowe dla narodowego teatru polskiego i teatru przyszłości, zawartych w słynnej XVI prelekcji Adama Mickiewicza w College de France z 24 kwietnia 1843 roku, Promethidionie Norwida oraz Studium o Hamlecie Wyspiańskiego, które to Studium w jednym z listów do Kotlarczyka Juliusz Osterwa nazwał „Ewangelią dla ludzi polskiego teatru”, dołączył Kotlarczyk Króla-Ducha Juliusza Słowackiego.

Wybór Króla-Ducha, wieloczęściowego, obszernego poematu wizyjnego, o głębokich historiozoficznych treściach i ładunku metafizycznym, utworu niescenicznego i trudnego do udźwignięcia na scenie, miał też inne, nader ważne odniesienia. Kotlarczyk już wcześniej podczas głośnego odczytywania jego epickich rapsodów dostrzegł nieznane mu dotąd pokłady piękna poetyckiego słowa i urodę warstwy brzmieniowo-muzycznej, nieczytelne przy cichej lekturze.

Spostrzeżenie to odniósł Mieczysław Kotlarczyk także do innych tekstów i wprowadził do praktyki teatralnej jako jedną z zasadniczych, koronnych wręcz zasad programowych. Podstawowe założenia dotyczące przejmowanego, a w rzeczywistości tworzonego na podstawie poszerzonego składu ,rozbitków Studia 39” zespołu Mieczysława Kotlarczyka zostały wyłożone przezeń podczas spotkania, 22 sierpnia 1941 roku w mieszkaniu państwa Dębowskich, a szerzej sprecyzowane zostały przez Kotlarczyka później, w manifeście programowym Teatr Nasz. Karol Wojtyła, który 
zajął się sprawami organizacyjnymi, związanymi z przygotowaniem tego spotkania, polecił wcześniej wszystkim adeptom zapoznać się z Królem-Duchem. Kotlarczyk, który poza Wojtyłą i Haliną Królikiewicz nie znał nikogo z tych młodych ludzi, dokonał zapewne za wskazaniami Wojtyły wstępnej obsady ról, w kilka tygodni później dodatkowo zweryfikowanej.

Danuta Michałowska w książce Pamięć nie zawsze święta pisze, iż powiadomiona osobiście przez Karola Wojtyłę o terminie, miejscu spotkania i potrzebie przyniesienia egzemplarza poematu, nabyła egzemplarz Króla-Ducha, który przeszedł do legendy teatralnej rapsodyków.

Natychmiast po wyjściu z biura - wspomina - udała się do księgarni przy ul. Podwale 6 [...] należącej naówczas do pana Stefana Kamińskiego; dostałam bez trudu broszurowe - najwspanialsze - wydanie Króla-Ducha Słowackiego, tzw. wydanie Pawlikowskiego: dwa olbrzymie tomiszcza: I tom - teksty, II - komentarz: Teksty ustalili i komentarzem opatrzyli Jan Gwalbert i Michał Pawlikowscy.

Te tomy, oprawione później w granatowe płótno, mam do dziś; pierwszy jest mocno sfatygowany, bo przez wiele lat służył do pracy, w dodatku odbył jedną długą podróż zagraniczną: w roku 1966 w Polskim Ośrodku Kulturalnym (tzw. POSK-u) w Londynie grał w moim montażu, zatytułowanym Skąd wyrosto to imię - poświęconym Papieżowi z okazji pięćdziesiątej rocznicy kapłaństwa, jako bezcenny rekwizyt: tę księgę trzymał w rękach Karol Wojtyła recytując jeden z fragmentów Króla-Ducha w czasie prapremiery 1 listopada 1941 roku w Krakowie. Fragment ten (była to parafraza Bogurodzicy) mówiliśmy wtedy na troje: Karol w środku, z jego lewej strony Halina Królikiewiczówna, z prawej ja. (Pamięć nie zawsze święta 133)

Pierwotnie skład wykonawców miał być szerszy, ale już po kilku próbach trzon zespołu tworzyli: Krystyna Dębowska, Halina Królikiewiczówna, Danuta Michałowska i Karol Wojtyła. Rzeźbiarz Tadeusz Ostaszewski został scenografem, a Mieczysław Kotlarczyk, który był reżyserem i inscenizatorem wszystkich okupacyjnych premier, zarezerwował sobie miejsce w obsadzie aktorskiej. Poza zespołem znaleźli się współpracujący z rapsodykami Juliusz Kydryński i Wojciech Żukrowski, a Tadeusz Kwiatkowski wystąpił dopiero w ostatniej premierze okupacyjnej - w Samuelu Zborowskim Juliusza Słowackiego.

Okupacyjna działalność zespołu Mieczysława Kotlarczyka była nie tylko formą konspiracyjnej walki, ale także znaczącym eksperymentem artystycznym.

Realia wojenne - stwierdza Bolesław Taborski - doprecyzowały eksperyment. Biorąc na warsztat długie epickie poematy lub równie długie „rozwichrzone”, jak się wtedy mówiło, dramaty poetyckie, aranżowali je w logiczne struktury, zachowując - jak w wypadku Króla-Ducha Słowackiego, zaledwie jedną dziesiątą tekstu. (Taborski 220)

Przy tak przyjętej strategii konstruowania spektaklu zrezygnowano zasadniczo z nurtu filozoficznego, zawartego w Królu-Duchu, z jego mistyczno-metafizycznym światem i wielokulturowością, na rzecz spójnego wyodrębnienia charakteru epopei narodo- 
wej, z licznymi obrazami życia narodu z zamierzchłej przeszłości, powiązanych tradycjami jeszcze przedchrześcijańskimi i wczesnopiastowskimi.

Od początku scenicznej działalności nie same ograniczenia okupacyjne (spektakle odbywały się wyłącznie w mieszkaniach zaprzyjaźnionych krakowskich rodzin, brak kurtyny, reflektorów, rezygnacja z teatralnej z szminki, ograniczenie oprawy scenograficznej, a kostiumów aktorskich do swoistego uniformizmu), ale nade wszystko konsekwentnie realizowana koncepcja teatralna spektaklu, jako wieczoru artystycznego, obejmującego szereg ustępów Króla-Ducha, tworzących teatralną kompozycyjną całość, zdawały się zapowiadać konsekwentnie przemyślaną formą jakość artystyczną w zespole Mieczysława Kotlarczyka. Nie była to wszakże tradycyjnie pojęta recytacja, bowiem z czasem, gdy zespół stopniowo coraz lepiej potrafił sprostać zadanym mu funkcjom, aktorzy - recytatorzy coraz wyraziściej nieśli idę słowa. A to stawiało przed nimi inne powinności interpretacyjne i głębokie przemyślenia tekstu. Szczególnie trudna powinność udźwignięcia swojej roli przypadała teraz Karolowi Wojtyle. Mieczysław Kotlarczyk powierzył mu prowadzenie kolejnych epizodów w ,sytuacjach”, a także słynny monolog Bolesława Śmiałego - naczelny wątek rapsodu $\mathrm{V}$, wieńczący spektakl. Właśnie te powinności interpretacyjne i przemyślenia nader trudnego i złożonego tekstu, który w różnych odczytaniach dawał niemałe możliwości interpretacyjne, przyniosły zaskakujące efekty, nie tylko artystyczne. Danuta Michałowska, wspominając tamte zdarzenia, stwierdza:

Karol Wojtyła mówił go [monolog Bolesława Śmiałego z rapsodu V - przyp. red.] wspaniale. Już w czasie prób słuchaliśmy go z podziwem i dreszczem grozy, ale owego pierwszolistopadowego wieczora osiągnął najwyższy stopień ekspresji artystycznej. Było to wykonanie pełne napięć, dynamiki, nie zatracające jednego odcienia znaczeniowego. Przedstawił te dramatyczne zdarzenia z tak pełnym zaangażowaniem, że wierzyło się każdemu słowu, a szczególny urok osobowości samego Karola, jednał sympatię dla nieszczęsnego monarchy. (Karol Wojtyła. Artysta i kapłan 38)

W Kronice Teatru Rapsodycznego, pisanej w latach 1948-1949, Danuta Michałowska podkreślała umiejętności aktorskie i indywidualizm rapsodyczny młodego Karola Wojtyły. Warto zauważyć, że stwierdzenia te pochodzą z czasów, gdy niedawno wyświęcony kapłan Wojtyła przebywał na studiach specjalistycznych w Rzymie. Było to więc na wiele lat przed rozpoczęciem jego kariery w strukturach hierarchicznych Kościoła.

Ani przedtem, ani potem nigdy nie słyszałam, aby się zdobył w tym czy innym fragmencie na tak wspaniałą siłę wyrazu, na takie wstrząsające dramatyczne przeżycie. My, którzy uczestniczyliśmy we wszystkich próbach i znaliśmy każdy akcent na pamięć - staliśmy oniemiali i zaklęci. (Michałowska, rkps 7) 
Jakie było zaskoczenie i zdziwienie zespołu rapsodyków i innych uczestników tamtego premierowego spektaklu, gdy dwa tygodnie później, w innym mieszkaniu i przed zasadniczo inną publicznością Karol Wojtyła wystąpił z całkowicie odmienną interpretacją tych fragmentów V rapsodu. Danuta Michałowska napisała:

Wszystko idzie normalnym, szczegółowo wypracowanym torem: historia Rytygiera (zwanego przez Słowackiego Ryżym Tygrysem), śmierć Wandy, zabójstwo wędrownego rapsoda Zoriana, Ziemowit wielkie zwycięstwo Słowian nad wojskami cesarza, przepiękna parafraza Bogurodzicy [...] Czekamy jednak w napięciu na finalny, tętniący dramatyzmem rapsod V, ten o Bolesławem Śmiałym. I oto dzieje się coś niebywałego: Karol przedstawia najzupełniej odmienną wersję tego samego przecież tekstu. Mówi cicho, monotonnie, w sposób doszczętnie pozbawiony owych przejmujących tonów namiętności, pychy, buntowniczej pasji, a także rozpaczy wobec zarysowującego się upadku państwa, nad którym zaciążyła klątwa króla.

Jesteśmy zaskoczeni, rozczarowani i - po prawdzie - oburzeni. Zasypujemy Karola pytaniami, zarzutami: „Co się stało? Jak mogłeś ? Dlaczego?!” Pamiętam dobrze zdumiewający sens jego odpowiedzi: „Przemyślałem sprawę; to jest spowiedź. Tego chciał Słowacki. (Karol Wojtyła. Artysta i kaptan 40-42)

Sama Michałowska wyznaje, że podobnie jak jej koleżanki - rapsodyczki - nie mogła pogodzić się z tą rezygnacją Karola Wojtyły z pierwotnej jego „premierowej” interpretacji monologu króla Bolesława z rapsodu V. Z pomocą w zrozumieniu jego decyzji przyszedł sam Juliusz Słowacki, który w rapsodzie I napisał:

I któż by śmiał w księgi ludzkie włożyć

Dla sławy marnej, a nie dla spowiedzi ? -

Postanowiłem niebiosa zatrwożyć,

Uderzyć w niebo tak jak w tarczę z miedzi.

Zbrodniami przedrzeć błękit i otworzyć,

I kolumnami praw, na których siedzi

Anioł żywota, zatrząść tak z posady

Aż się pokaże Bóg w niebiosach - blady.

Warto podkreślić, że właśnie w Królu-Duchu Karol Wojtyła jako pierwszy dotknął najgłębiej istoty rapsodyzmu i jego intelektualnego fenomenu, o którego istocie napisał w 1952 roku w szkicu O Teatrze Słowa. Pięć lat później niektóre praelementy scenicznego rapsodyzmu, jego odrębność artystyczną i istotę sformułował w studium Dramat słowa i gestu. Wierny nadrzędnemu przesłaniu, według którego aktor „,uobecnia” poprzez słowo, prawdę i piękno, dokonał Wojtyła ideowej i artystycznej rewizji swojego sposobu interpretacji scenicznej owego rapsodu V. Podłoże tej zmiany interpretacji scenicznej mogło być dodatkowo pogłębione nie tylko dogłębnymi przemyśleniami tekstu Juliusza Słowackiego, ale i ostatecznymi refleksjami i przewartościowaniami natury duchowej. Zdaniem Danuty Michałowskiej, „W czasie tych dwóch tygodni, dzielących pierwszą i drugą interpretację rapsodu 
o Bolesławie Śmiałym doszło do głosu najgłębsze, istotne powołanie: już nie artysty, lecz kapłana" (Karol Wojtyła. Artysta i kaptan 44).

O której interpretacji: pierwotnej czy ostatecznej monologu Bolesława Śmiałego z rapsodu V mówił Juliusz Osterwa, przepowiadając Karolowi Wojtyle tak świetną aktorską przyszłość? Zarówno Danuta Michałowska - występująca w Królu-Duchu - jak i obecny na próbach oraz spektaklach Tadeusz Kwiatkowski, zgodnie potwierdzali, że słyszeli te słowa, padające z ust Osterwy, ale nie byli zgodni w odniesieniu do tego, w którym z czterech spektakli okupacyjnego Króla-Ducha Osterwa jako widz uczestniczył. Bezsporne było ich świadectwo wypowiedziane przez Osterwę w kwestii oceny talentu aktorskiego młodego Wojtyły.

Warto podkreślić, że Karol Wojtyła wielokrotnie powracał do królów - duchów z rapsodów Juliusza Słowackiego. Jako arcybiskup metropolita krakowski, spadkobierca - sukcesor stolicy biskupiej krakowskiej, którą często nazywał zgodnie z wielowiekową tradycją, stolicą biskupią świętego Stanisława, był piastunem tradycji św. Stanisława, ale poszukującym prawdy o Stanisławie ze Szczepanowa i królu Bolesławie. Zainicjowane przez Karola Wojtyłę sesje naukowe z udziałem wybitnych specjalistów, poświęcone genezie i przebiegowi konfliktu pomiędzy królem i hierarchą, a także następstwom tego krwawego konfliktu, które z braku dostatecznych źródeł i świadectw, choć wiele podpowiedziały, niczego dodatkowo w istocie nie wyjaśniły. Badania czaszki św. Stanisława, wydobytej ze słynnego szczerozłotego późnogotyckiego relikwiarza, wybitnego dzieła krakowskiej sztuki złotniczej Marcina Marcińca, przeprowadzone z inicjatywy arcybiskupa Karola Wojtyły, potwierdziły opisywaną w średniowiecznych kronikach Kadłubka i Długosza, utwierdzone wielowiekową, odwieczną tradycją, bezpośrednią przyczynę śmierci biskupa Stanisława.

Sam Karol Wojtyła - odtwórca rapsodycznej roli króla Bolesława, skonfliktowanego z biskupem Stanisławem, w poszukiwaniu motywacji działania i racji obu bohaterów, dookreślenia ich postaw czy interpretacji tamtych wydarzeń, poszedł drogą właśnie Juliusza Słowackiego. Na nadchodzącą 900 rocznicę śmierci biskupa Stanisława ze Szczepanowa kardynał Karol Wojtyła napisał poemat Stanisław, traktat o „ziemi trudnej jedności”. I pewnie obaj poeci: wieszcz i młodszy od niego o ponad wiek Romantyk Boży - Karol Wojtyła, ten zapowiedziany - wielki oczekiwany przez autora Króla-Ducha, „Papież słowiański”, byli zgodni w zasadniczej ocenie: Bolesław i Stanisław byli ludźmi nieprzeciętnymi. Poemat ten ukończył kardynał Wojtyła na kilka kwadransów przed udaniem się na pamiętne konklawe, podczas którego obrany został papieżem, a jako papież przekazał jego rękopis swojemu następcy na krakowskiej stolicy biskupiej ks. Franciszkowi Macharskiemu w dniu jego konsekracji biskupiej, 6 stycznia 1979 roku, jako dziedzictwo kluczy.

To wyzbyte efektownych form retoryki, mierzenie się aktora $\mathrm{z}$ zawartą $\mathrm{w}$ romantycznych rapsodach ideą słowa, przez koleżanki z rapsodycznego zespołu jeszcze 
niedostatecznie zgłębione, stało się probierzem bodaj najgłębszego w literaturze polskiej odczytania istoty i następstw odległych wydarzeń z XI stulecia. Dziedzictwem głęboko przemyślanym tamtego rapsodycznego Króla-Ducha był poemat Stanisław.

Następna premiera, którą przygotowali rapsodycy, była także oparta na twórczości Juliusza Słowackiego. Warto podkreślić, że aż trzy spośród siedmiu okupacyjnych premier Teatru Rapsodycznego dotyczyły utworów właśnie tego poety.

\begin{abstract}
Słowackiego uważaliśmy zawsze za największego mistrza i wirtuoza języka polskiego, na nim chcieliśmy kształcić i doskonalić sztukę wygłaszania polskiego słowa; jemu też poświęciliśmy nasze drugi z rzędu wieczór. W Beniowskim dostrzegliśmy nie tyle Iliadę Barską, ile poemat par excellence autobiograficzny, najbardziej spośród dzieł Słowackiego osobisty, wspaniały, śpiew o sobie samym.

Realizacja tak pojętego poematu opierała się o założenie, że działają w nim trzy dramatis persone: Słowacki - człowiek, Słowacki - artysta i Słowackiego Poezja, jego Słowa. (Kotlarczyk, „Teatr Rapsodyczny” 160)
\end{abstract}

Zindywidualizowanie dwóch Słowackich w jego dziele, dwóch profilów poety, wzięło na swoje barki dwóch odtwórców: Mieczysław Kotlarczyk i Karol Wojtyła. Swoiście pojęte upostaciowienie Poezji i Słowa przypadło trzyosobowemu chórowi (D. Michałowska, K. Dębowska, H. Królikiewicz). Karolowi Wojtyle powierzone zostały partie dotyczące Słowackiego - artysty, on też wygłaszał apostrofę do Ludwiki Śniadeckiej.

Odbył się tylko jeden, premierowy pokaz (14 lutego 1942, w mieszkaniu pp. Dębowskich przy ul. Komorowskiego 7). Realizacja tak pomyślanego spektaklu, jak i sposób interpretacji tekstu przez aktorów spotkały się z krytyką ze strony krakowskiego aktora, Władysława Woźnika. Wobec aktorów wysunął on zarzut, że nie umieją recytować tekstu poetyckiego. Ale w tej ocenie nie wszyscy podzielali opinie Beniowskiego porywczego aktora. O znakomitym warsztacie recytatorskim oraz umiejętności intelektualnego zmagania się z tekstami Słowackiego wypowiadał się Tadeusz Kudliński, który w czerwcu 1942 roku występował do władz „Unii” z wnioskiem o przyznanie nagród dla piątki aktorów Teatru Rapsodycznego, a wśród nich dla Karola Wojtyły za rolę Bolesława Śmiałego w Królu-Duchu i za pojedynek Słowackiego z Mickiewiczem w Beniowskim.

Kolejna chronologicznie premiera, Hymny Kasprowicza (28 marca 1942) należała do najważniejszych w sensie artystycznym i ideowym osiągnięć rapsodyków w okresie okupacyjnym. Zamysł ich wystawienia pochodził najpewniej od Karola Wojtyły, od lat zafascynowanego twórczością poetycką Kasprowicza. Niezwykle cenne świadectwo w tym względzie daje Jacek Popiel, uczeń Kazimierza Forysia w wadowickim liceum, tego samego Forysia, który w okresie przedwojennym był nauczycielem Karola Wojtyły i opiekunem Kółka Teatralnego przy wadowickim liceum: 
Wspomniany już Kazimierz Foryś - pisze J. Popiel - opowiadał mi, że już w okresie wadowickim utwory składające się na późniejszy spektakl Kotlarczyka (Święty Boże, Święty Mocny; Salve Regina; Salome; Maria Egipcjanka; Judasz; Dies Irea; Moja pieśń wieczorna; Hymn św. Franciszka) należały do ulubionych tekstów młodego Wojtyły, których fragmenty potrafił cytować z pamięci. Można przypuszczać, że zaproponowany przez Kotlarczyka układ kompozycyjny, ujmujący utwory Kasprowicza w tryptyk: bunt - pokuta - ukojenia, odpowiadał przemyśleniom religijno-artystycznym Wojtyły [...] Wiemy również, że w recytacji zbiorowej hymnu Święty Boże Wojtyła był osobą prowadzącą. Natomiast w finale spektaklu samodzielnie interpretował Hymn św. Franciszka. (Popiel 275)

Jakkolwiek Hymny Kasprowicza należały do najwyższych osiągnięć rapsodyków okresu okupacji, odbyła się tylko premiera w mieszkaniu Goreckich na Kleparzu - ale do konspiracyjnych doświadczeń, podobnie jak w przypadku Beniowskiego, powrócił Kotlarczyk z Hymnami, z konieczności w innej, szerszej obsadzie, już w 1945 roku. Danuta Michałowska w cytowanej książce Pamięć nie zawsze święta podnosiła znakomitą interpretację Mieczysława Kotlarczyka w roli Judasza, Karola Wojtyły i Krystyny Dębowskiej („,Karol mówił bardzo pięknie Hymn św. Franciszka, a Krysia Salome" - 150).

Kasprowicz i Wyspiański, najwięksi - zdaniem Karola Wojtyły - kontynuatorzy i artystycznie samodzielni spadkobiercy wielkiej trójki romantyków: Mickiewicza, Słowackiego oraz Norwida w sposób przemożny oddziaływali na kierunki myślenia Wojtyły, jego fascynacje artystyczne i ideowe, czy religijno-moralne rozstrzygnięcia. W przypadku Stanisława Wyspiańskiego pole tych inspiracji i oddziaływań było szersze, bo dotyczyło także poczynań literackich: Psalterza Dawidów (Księgi słowiańskiej) i tzw. dramatów polonistycznych Karol Wojtyły.

Następna premiera - Godzina Wyspiańskiego była ostatnią w pierwszym sezonie artystycznym konspiracyjnego Teatru Rapsodycznego. Odbyła się ona 22 maja 1942 roku w mieszkaniu Danuty Michałowskiej przy ul. Szlak 21. Na przedstawienie złożyły się fragmenty zarówno znanych i popularnych dramatów Wyspiańskiego, jak i teksty z rzadka wystawiane i przez nielicznych specjalistów doceniane. Tekstami wiodącymi były fragmenty Wesela, Akropolis i Studium o Hamlecie. Spektakl był trzyczęściowy, stworzony na jakieś ideowe pokrewieństwo z Beniowskim: pierwszy akt poświęcony był Wyspiańskiemu - człowiekowi teatru; drugi - polskiej niełatwej przeszłości (tu były m.in. fragmenty Wesela ze znakomitą rolą Karola Wojtyły w roli Jaśka); trzeci - polskiemu zwycięskiemu jutru, z tekstem Akropolis.

Na jednym z czterech przedstawień Godziny Wyspiańskiego pojawił się znów, po dłuższej przerwie, Juliusz Osterwa, który odtąd bywał na konspiracyjnych spektaklach częstym gościem i bronił aktorów przed ponawianymi zarzutami W. Woźnika, że nie opanowali dostatecznie warsztatu aktorskiego. „Osterwę najbardziej zafascynowała - stwierdza Jacek Popiel - rola słowa w teatrze Kotlarczyka. W sposobie jego interpretacji i miejscu w całości środków teatralnego wyrazu dostrzegał oryginalność 
Rapsodyków. Za patrona tego teatru uważał Norwida z jego przemyśleniami na temat Słowa i Czynu..." (Popiel 174).

Nowy sezon teatralny rapsodycy zapoczątkowali premierą opartą na twórczości poety-filozofa, Cypriana Kamila Norwida. Artysty zatem szczególnie bliskiego zarówno Kotlarczykowi, jak i Wojtyle. Próby na ogół odbywano w mieszkaniu wspólnie przez nich zajmowanym przy ulicy Tynieckiej10, ale premiera ze względu na szczupłość miejsca odbyła się w mieszkaniu Heleny Ligockiej, przy ulicy Potockiego 2. Mimo że rapsodyków najbardziej interesowała twórczość dramaturgiczna Norwida, zrezygnowano z porywających dialogów, aby - jak stwierdzał Mieczysław Kotlarczyk - „na trudniejszym może tekście przejść bardziej ćwiczącą drogę” (XXV lat Teatru Rapsodycznego 26).

Dobrane teksty miały tworzyć portret artysty-filozofa, kreatora koncepcji narodowej sztuki, skazanego na zapomnienie, przez wiele dziesięcioleci niezrozumianego i zarzuconego. Na literacki portret artysty złożyły się: Rzecz o wolności stowa, Fortepian Chopina, Polka, Epos nasza i szczególnie ceniony przez Karola Wojtyłę Promethidion. Obecny na premierze Juliusz Osterwa nie ukrywał zachwytu, zarówno w odniesieniu do scenariusza, zwartej i wyrazistej, nośnej koncepcji artystycznej, intelektualnie przemyślanej, jak i wysokiego poziomu aktorskiej prezentacji. Watro podkreślić, że Karol Wojtyła w przyszłości wielokrotnie będzie odwoływał się do tych i wielu innych utworów Norwida. Już w okresie studiów polonistycznych w rapsodzie Słowo - $\Lambda$ ОГО $[$ Logos], z tomiku młodzieńczego Psalterz Dawidów (Księga słowiańska), wystąpiły pokrewieństwa ideowe, ale ujęte samodzielnie, w odniesieniu m.in. do wykładni Logosu, w poemacie Promethidion. Norwid pozostawał będzie wielokrotnie przedmiotem homiletycznych, filozoficznych odwołań ks. Karola Wojtyły, a w słynnym Liście do artystów Jana Pawła II był przytaczany jako zwornik najgłębszych odniesień, wespół z utworami ścisłej klasyki filozoficzno-estetycznej świata.

Po premierze norwidowskiej Portret Artysty sytuacja w zespole rapsodyków uległa zmianie, zrazu wydawałoby się mało zauważalnej, ale w nieodległej przyszłości dla dalszego funkcjonowania Teatru Rapsodycznego bardzo znaczącej. Jesienią 1942 roku filar zespołu Mieczysława Kotlarczyka i jego najbliższy współpracownik artystyczny podjął studia teologiczne na konspiracyjnie funkcjonującym Wydziale Teologicznym Uniwersytetu Jagiellońskiego. Pierwotnie zamierzał wstąpić do nowicjatu u karmelitów bosych w podkrakowskiej Czernej, ale - zapewne pod wpływem Tadeusza Kudlińskiego zrezygnował z tego zamysłu, ale tylko nieznacznie, bo zmienił nowicjat (oficjalnie decyzją władz okupacyjnych zamknięty) na rzecz konspiracyjnego seminarium diecezjalnego. Nadal mieszkał na Dębnikach razem z Kotlarczykami, pracował w Zakładach Sodowych „Solvay” i studiował teologię 
na tajnych kompletach uniwersyteckich. Jako kleryk uczestniczył jeszcze w przygotowaniu dwóch następnych premier: Pana Tadeusza i Samuela Zborowskiego.

Premiera Pana Tadeusza odbyła się 28 listopada 1942 roku w mieszkaniu pp. Goreckich na Kleparzu. W trzyczęściowym spektaklu główną i wiodącą w spektaklu rolę powierzył reżyser Karolowi Wojtyle. Do legendy artystycznej okupacyjnego Krakowa przeszła jego słowna konfrontacja z niemiecką krzykaczką, zapisana przez uczestnika przedstawienia, Tadeusza Kwiatkowskiego:

Jeszcze dziś przechodzą mnie ciarki, gdy to wspominam. Wojtyła, który tymczasem wyrósł na głównego i najlepszego aktora zespołu, recytował powoli, z wyraźnym wewnętrznym skupieniem fragmenty spowiedzi księdza Robaka. Naraz w ciszy, jaka zapanowała, odezwał się głośnik niemieckiego radia zainstalowany naprzeciw kamienicy Goreckich przy placu Kleparskim. „Wir bringen die Nachrichten in polnicher Sprache. Główna kwatera Naczelnego Wodza podaje do wiadomości..." i padały słowa o zwycięstwach, jakie odniósł oręż niemiecki nad Europą. Karol, jak gdyby nie słyszał tych buńczucznych zdań, nie przerwał, nie zmienił tonu. Mówił cicho, spokojnie, jakby nic poza jego słowami nie istniało na świecie, jakby zwierzał się nam z czegoś najbliższego sobie, ważniejszego od trzęsienia ziemi i wrogich żywiołów. Mickiewicz w jego interpretacji nie podjął krzykliwej walki. Kiedy krzykaczka skończyła pochwałę hitlerowskich zbrodni, Mickiewicz głosił pojednanie Soplicy z klucznikiem. [...] Czuliśmy się wszyscy synami narodu, który, choć niejednokrotnie oszukany na przestrzeni wieków, nie ulegnie przemocy. Chwila była osobliwa. (Płaci się każdego dnia 130)

W tej samej wspomnieniowej książce Płaci się każdego dnia, dokumentującej m.in. fenomen życia artystycznego w okupowanym Krakowie, Kwiatkowski stwierdził:

Wojtyła zapowiadał się na wielkiego aktora. Miał warunki nie tylko fizyczne, choć zwykle chodził z pochyloną głową i nieco skulonymi ramionami, i czysty, dźwięczny głos, ale posiadał to, co aktorzy nazywają wnętrzem. Wypowiadane przez niego słowa niosły często znaczenia, których niełatwo się było dopatrzeć przy lekturze, czy nawet w wykonaniu innych aktorów. Nie był nigdy nadto rozmowny i wolny czas spędzał w domu ucząc się i czytając. (130)

Pod koniec 1942 roku, wkrótce po premierze Pana Tadeusza Kotlarczyk napisał wspomniany już, kilkustronicowy tekst o charakterze programowym Teatr NASZ. Zawierał on nie tylko plany repertuarowe, ale i istotę artystycznej odrębności od innych zespołów teatralnych.

Ostatnia, zrealizowana premiera podziemnego Teatru Rapsodycznego - Samuel Zborowski Juliusza Słowackiego, odbyła się wiosną 1943 roku.

[...] Samuela Zborowskiego rozegrano - stwierdza Małgorzata Dziedzic - jako fantastyczną symfonię wizyjną. Rzecz zaczynała się wersetami z Apokalipsy, wizją słonecznej Jerozolimy, następnie znać było w nim jakieś średniowieczne tryptyki - a dopiero na tle tych wizyjnych, mistycznych scen jawił się konflikt i proces Zborowskiego. (M. Dziedzic 26) 
W roli tytułowej występował Karol Wojtyła, Lucyfera grał Mieczysław Kotlarczyk, a chór tworzyły: Danuta Michałowska, Krystyna Dębowska i Halina Królikiewicz. Gościnnie wystąpili także: Tadeusz Kwiatkowski i Antoni Żuliński. Spektakl cieszył się dużym zainteresowaniem, prezentowano go 6 razy. Na jednym z przedstawień byli obecni członkowie Delegatury Rządu na Kraj. Ten dramat niesceniczny, oparty na lirycznych i epickich monologach wzbudzał zachwyt. Danuta Michałowska w Kronice pisze szerzej o entuzjastycznych reakcjach widzów, m.in. Zofii Kossak-Szczuckiej, znanego krytyka muzycznego Regameya czy Stanisława Wiktora Balickiego, stwierdza też:

Koroną premier okupacyjnych był Samuel Zborowski. Najwyższy ciężar gatunkowy tekstu, wielka praca nad wykonaniem, rozszerzenie zespołu, oryginalna muzyka, no i fakt, że była to ostatnia zrealizowana w czasie okupacji premiera - nie z naszej winy zresztą ostatnia. [...]

Pani Władzia Markiewiczówna napisała do tego tekstu muzykę - była to muzyka bardzo nowoczesna i trudna, ale przywiązaliśmy się do niej bardzo. Nigdy chyba strof o „mieście, które jest pięknością, pożarem, miłością, wiarą wiar, stolicą stolic..." nie potrafię w myśli oddzielić od pełnych szklanych akordów triumfalnego hymnu o nowej Jeruzalem. (33)

Karol Wojtyła nie uczestniczył już w przygotowaniach do następnej premiery, na którą miały się złożyć fragmenty dwóch dramatów Karola Huberta Rostworowskiego - Miłosierdzie i Straszne dzieci. Byłaby to pierwsza w istocie premiera oparta na realistycznych dramatach scenicznych. Nie doszła ona do skutku najpierw z powodu choroby Kotlarczyka, a później wypadków wojennych. Większość prób, jak dotąd, odbywała się w mieszkaniu Wojtyły. Ale były to próby już bez jego udziału, choć - jeśli nie był w pracy w Solvayu - w jego obecności.

Brakowało go bardzo. Wspominaliśmy nieraz melancholijnie ten czas, kiedy on właśnie, jeszcze przed przyjazdem Mietka, był duszą i spirytus movens całej naszej gromadki. Potem zawsze wnosił cały ogromny ładunek talentu i niepohamowanego młodzieńczego, radosnego entuzjazmu; kiedy udał się nam jakiś szczegół, Karol rzucał się na podłogę, stawał na głowie lub chodził na rękach [...] Poezja i sztuka aktorska były jego żywiołem. $[\ldots]$

A potem wszystko się zmieniło i siadywał zawsze na uboczu, milczący i nieobecny duchem

Tak więc Karol odchodził od nas - na zawsze. (Michałowska, Kronika 27)

Tytułową rolą Samuela Zborowskiego zakończył Karol Wojtyła swój ważny w jego życiu artystycznym epizod teatralny. Oddany nowemu powołaniu, zachował zawsze z rapsodykami bliskie i serdeczne związki, samemu zaś Mieczysławowi Kotlarczykowi okazywał pomoc, gdy Teatr Rapsodyczny został administracyjnie unicestwiony, a jego założyciel pozostawał bez pracy.

Najcenniejsze jednak świadectwo - stwierdza Jan Ciechowicz - swojego związku i przynależności do Teatru Rapsodycznego, który „uważał za swój”, dał ksiądz, a później biskup i Kardynał Ka- 
rol Wojtyła jako krytyk teatralny. Ukryty pod pseudonimami Piotra Jasienia i Andrzeja Jawienia wydrukował on na łamach „Tygodnika Powszechnego” w latach 1952-1961 cztery dość obszerne artykuły o teatrze słowa. To najlepsze stronice, jakie w ogóle napisano o Teatrze Rapsodycznym. (124)

W tych studiach i artykułach, dogłębnie dopracowanych, z usystematyzowaną merytoryczną spójnością i przenikliwością wywodu, zawarł Karol Wojtyła podstawy swojego teatralnego światopoglądu, u podstaw którego stoi eschatologia słowa, słowa pojmowanego jako praelement teatru. Tak pojęty teatr był światem myśli.

Teatrowi Rapsodycznemu wiele Wojtyła zawdzięczał, podobnie jak studiom polonistycznym, przerwanym wybuchem wojny, ale fenomen jego umiejętności organizatorskich sięgał swoimi podstawami głębiej. Dał temu kiedyś wyraz wybitny pisarz, publicysta i eseista, Andrzej Kijowski, wówczas student polonistyki Uniwersytetu Jagiellońskiego, młodszy od Wojtyły o osiem zaledwie lat, uczeń w większości tych samych krakowskich profesorów uniwersyteckich. Po wysłuchaniu jednego ze słynnych już kazań młodego wikarego z kościoła św. Floriana wspominał:

Matka kazała mi pójść posłuchać go. Usłyszawszy raz, chodziłem potem co niedzielę, w sekrecie przed otoczeniem, przed którym manifestowałem antyklerykalizm i ateizm. [...]

Wszystko, co mówił, było mi znane i wszystko było zaskakujące. Wydawało mi się, że gdyby mi przyszło mówić o tym, o czym on mówił - ująłbym to tak jak on, a wiedziałem jednocześnie, ze nigdy by mi to nie przyszło do głowy. Analizować postać Jezusa tak, jak się na seminarium Wyki analizowało postać literacką, ale mówił jako o człowieku żywym. Mówił o boskości ewangelicznego przesłania, a zarazem o strukturze ewangelicznej narracji. Wprowadzał postać Ewangelisty jako uczestnika Chrystusowego dramatu, jako świadka i jako pośrednika; pomiędzy Chrystusem a nami zjawił się pisarz. Wyjaśniał tajemnicę zbawienia przez wielość warstw, z których składa się Dobra Nowina. Teologia i antropologia stanowiły w jego homiliach całość, jedność.

I wszystko w nich było jasne. Jasne były słowa, jasne brzmienie głosu, nawet wymowa głosek była jasna - i jasne spojrzenie, które rzucał z czarno-złotej ambony naszego kościoła. (Cyt. za: Szczypka 141)

I tak już pozostało, gdy odsłonił bogactwo swojego charyzmatu, gdy porywał na wielkich placach, stadionach i w bazylikach miliony ludzi. Rapsodyk Słowa Odwiecznego.

\section{BIBLIOGRAFIA}

Burghardt, Marta. Wadowickie korzenie Karola Wojtyly. Wadowickie Centum Kultury, 2013.

Ciechowicz, Jan. Dom opowieści. Ze studiów nad Teatrem Rapsodycznym Mieczysława Kotlarczyka. Wydawnictwo Uniwersytetu Gdańskiego, 1992.

Dziedzic, Małgorzata. Teatr Rapsodyczny w Krakowie (1941-1967), Kraków, mps, 1987. 
Dziedzic, Stanisław. „Pomocnik światła. Rapsodyczne lata Karola Wojtyły”. Rzeczy minionych pamięć. Studia dedykowane Perofesorowi Tadeuszowi Ulewiczowi w 90. rocznice urodzin, red. Andrzej Borowski i Jakub Niedźwiedź, Wydawnictwo Księgarnia Akademicka, 2007.

Dziedzic, Stanisław. „Romantycy w inscenizacjach podziemnego Teatru Rapsodycznego”. Dialog dwóch kultur 2018, red. Grzegorz Nowik, Muzeum Józefa Piłsudskiego w Sulejówku, 2019, ss. 83-96.

Dziedzic, Stanisław. Romantyk Boży. Wydawnictwo M, 2014.

Dziedzic, Stanisław. „Rozbitek ze Studia 39”. Profesor Jolancie Żurawskiej. Studia ofiarowane przez kolegów i przyjaciół, red. Nullo Minissi i Wacław Walecki, Collegium Columbinum, 2008.

Jan Paweł II. Dar i Tajemnica. Wydawnictwo św. Stanisława BM, 1996.

Kotlarczyk, Mieczysław, i Karol Wojtyła. O Teatrze Rapsodycznym. Wstęp i oprac. Jacek Popiel, Państwowa Wyższa Szkoła Teatralna w Krakowie, 2001.

Kotlarczyk, Mieczysław. „Teatr Rapsodyczny w latach 1941-1945”. Pamiętnik Teatralny, t. 12, nr 1-4, 1963, ss. $155-164$.

Kotlarczyk, Mieczysław. XXV lat Teatru Rapsodycznego w Krakowie, 1941-1966. Teatr Rapsodyczny, 1966.

Kwiatkowska, Halina. Porachunki z pamięciq. Wydawnictwo Kwadrat, 2002.

Kwiatkowska, Halina. Wielki Kolega. Wydawnictwo Kwadrat, 2003.

Kwiatkowski, Tadeusz. „Karol”. Młodzieńcze lata Karola Wojtyły, red. Juliusz Kydryński, Oficyna Cracovia, 1990.

Kwiatkowski, Tadeusz. Płaci się każdego dnia. Wydawnictwo Literackie, 1986.

Malak, Tadeusz. „Polska będzie Lolusiu”. Teatr, nr 11, 1991, ss. 21-26.

Michałowska, Danuta. Karol Wojtyła. Artysta i kapłan. Wydawnictwo Prospekt, 2000.

Michałowska, Danuta. Kronika Teatru Rapsodycznego, rkps, 1949.

Michałowska, Danuta. Pamięć nie zawsze święta. Wspomnienia. Wydawnictwo Literackie, 2004.

Michałowska, Danuta. „Spotkanie z aktorem Teatru Rapsodycznego”. Dialog Kościoła z kultura, t. 1, red. ks. Stefan Misiniec, Kuria Metropolitalna w Krakowie, 1986.

Młodzieńcze lata Karola Wojtyły, red. Juliusz Kydryński, Oficyna Cracovia, 1990.

Pisarstwo Karola Wojtyly - Jana Pawła II w oczach krytyków i uczonych. Antologia, oprac. Krzysztof Dybciak, Państwowy Instytut Wydawniczy, 2019.

Popiel, Jacek. Los artysty w czasach zniewolenia. Teatr Rapsodyczny 1941-1967. Wydawnictwo Uniwersytetu Jagiellońskiego, 2006.

Słowacki, Juliusz. Dzieła, t. 4: Król-Duch, red. Julian Krzyżanowski, Państwowy Instytut Wydawniczy, 1949.

Szczypka, Józef. Jan Pawet II. Rodowód. Instytut Wydawniczy PAX, 1989.

Taborski, Bolesław. Wprost w moje serce uderza droga wszystkich. O Karolu Wojtyle-Janie Pawle II: szkice, wspomnienia, wiersze. Wydawnictwo Adam Marszałek, 2004.

Wojtyła, Karol - Jan Paweł II. Dzieła literackie i teatralne, t. 1: Juwenilia, (1938-1946), red. Jacek Popiel i in., Znak, 2019.

Wojtyła, Karol - Jan Paweł II. Dzieła literackie i teatralne, t. 2: Utwory poetyckie (1946-2003), red. Zofia Zarębianka, Znak, 2020.

\section{„ZAPOWIADA SIĘ NADZWYCZAJNY AKTOR”. KAROL WOJTYŁA W PODZIEMNYM TEATRZE RAPSODYCZNYM}

Streszczenie

Gdy w 1938 roku Karol Wojtyła, po zdaniu matury w wadowickim Państwowym Gimnazjum Męskim im. Marcina Wadowity, obrał studia polonistyczne na Uniwersytecie Jagiellońskim, decyzję tę przyjęto w rodzinnych Wadowicach bez oznak zaskoczenia. Powszechnie znano tam jego zaintereso- 
wania i predyspozycje teatralne: aktorskie i reżyserskie. Był filarem gimnazjalnego Kółka Teatralnego, występował także w Amatorskim Teatrze Powszechnym, prowadzonym przez Mieczysława Kotlarczyka, a także na scenie tamtejszego Domu Katolickiego. Jego mistrzem w zakresie sztuki teatralnej był Mieczysław Kotlarczyk. Gimnazjalista Wojtyła podejmował już wówczas próby poetyckie, być może z tego okresu pochodziły liryki z zaginionego zbioru Ballady beskidzkie.

Chciał być aktorem, rozwijał też aktywność literacką. Kraków z jego środowiskami twórczymi oraz studenckie grono rówieśnicze sprzyjały rozwojowi poszukiwań teatralnych i literackich. Obok studiów uniwersyteckich, kształcił swój warsztat aktorski w Studium Dramatycznym 39. W okresie okupacji hitlerowskiej „rozbitkowie” Studia 39 w warunkach konspiracyjnych kontynuowali działalność teatralną, a po przyjeździe do Krakowa Mieczysława Kotlarczyka (1941) zespół przekształcono w Teatr Rapsodyczny. Wojtyła występował we wszystkich siedmiu premierach tego zespołu. Z jego talentem i możliwościami aktorskimi, a także głęboką wiedzą teoretyczną uczestnicy konspiracyjnych występów wiązali wielkie nadzieje teatralne. Doceniał jego talent sam Juliusz Osterwa, czołowy polski aktor teatralny, który stwierdził po przedstawieniu Króla-Ducha Juliusza Słowackiego: „Zapowiada się nadzwyczajny aktor" i zamierzał go zatrudnić po wojnie w swoim teatrze. Ale nadszedł czas os tatecznego wyboru: Karol Wojtyła jesienią 1942 roku wstąpił do Seminarium Duchownego. Rapsodyczne doświadczenia i literackie dokonania były probierzem umiejętności „porywania” wielomilionowych rzesz przez charyzmatycznego papieża.

Słowa kluczowe: Karol Wojtyła; Teatr Rapsodyczny; Studio Dramatyczne; ulica Tyniecka; Mieczysław Kotlarczyk

\section{"HE SEEMS AN EXTRAORDINARY ACTOR." KAROL WOJTYŁA IN THE UNDERGROUND RHAPSODIC THEATRE}

Sum mary

Karol Wojtyła's decision to start Polish Philology at the Jagiellonian University after graduating from the State Marcin Wadowita Secondary School was no surprise to those who knew him in Wadowice. His theatrical interests and talents, mainly acting and directing, were widely known. He helped found a high school theatrical group, acted in the Amateur Universal Theatre run by Mieczysław Kotlarczyk, and on the stage of the Catholic House. His mentor in the field of the theatre was Mieczysław Kotlarczyk. As a secondary school student, Wojtyła had already started writing poetry, and possibly his Beskid Ballads had already been created.

He wanted to become an actor, but also developed as a writer. Cracow, with its creative environment and student peers, supported his theatrical and literature endeavours. Besides his university studies, he also developed his acting skills in the Studio 39 theatre group. During the Nazi occupation of Poland, Studio 39 members continued their underground activities. After Mieczysław Kotlarczyk arrived in Cracow in 1941, the Studio was transformed into the Rhapsodic Theatre. Wojtyła participated in all 7 premiere performances. With his talent and acting capabilities, together with his deep theatrical knowledge, he was a rising hope for his underground companions in the field of acting. His skills were appreciated by such famous actors as Juliusz Osterwa. Osterwa, the chief Polish actor of those times, stated "We seem to have an extraordinary actor" after Juliusz Słowacki's Król-Duch was performed with Wojtyła starring. He intended to employ Wojtyła after the war. However, the time to make definitive choices finally arrived and Karol Wojtyła entered the Higher Seminary for Priests in 1942. His rhapsodic experience and literary achievements were to be the measurement of his charismatic call to millions of followers and believers as the future Pope.

Keywords: Karol Wojtyła; Rhapsodic Theatre; Studio 39; Tyniecka Street; Mieczysław Kotlarczyk 